
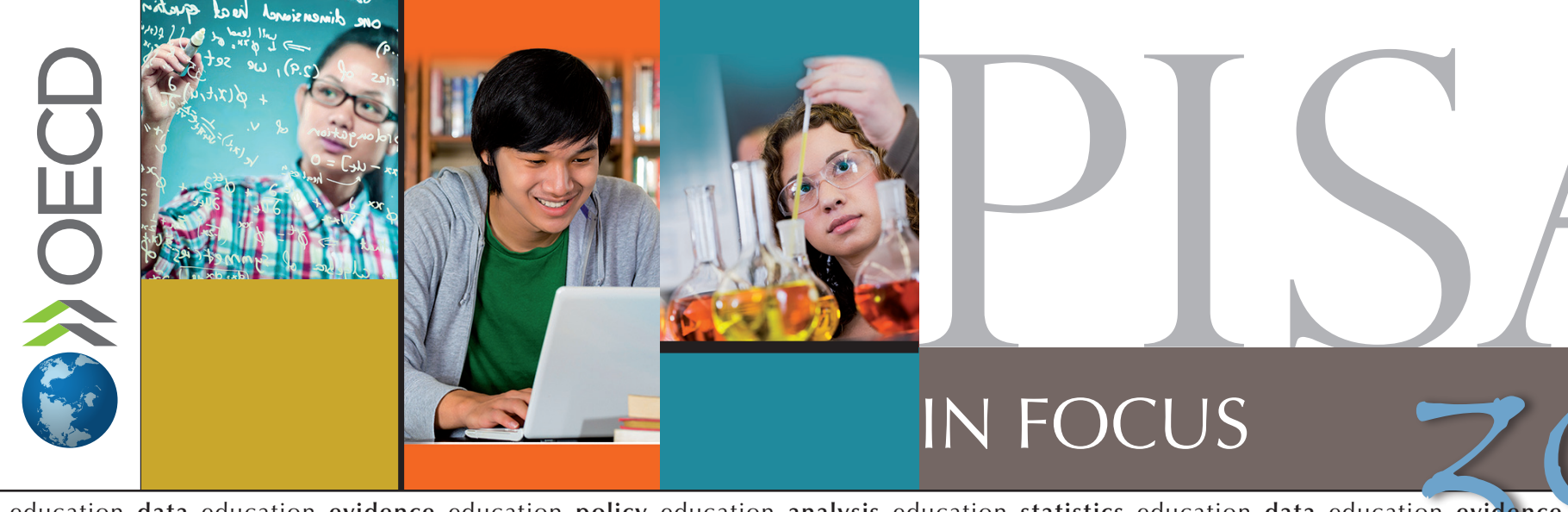

education data education evidence education policy education analysis education statistics education data education evidence education policy

\title{
Are grouping and selecting students for different schools related to students' motivation to learn?
}

- On average across OECD countries, students who are highly motivated to learn mathematics because they believe it will help them later on score better in mathematics - by the equivalent of half a year of schooling - than students who are not highly motivated.

- Students' motivation to learn mathematics is lower in education systems that sort and group students into different schools and/or programmes.

Motivation and engagement can be regarded as the driving forces behind learning. Given the importance of mathematics for students' future lives, school systems need to ensure that students have not only the knowledge that is necessary to continue learning mathematics beyond formal schooling, but also the interest and motivation that will make them want to do so.

Most students recognise that learning mathematics is important.
Students participating in PISA 2012 were asked to report the extent to which they are motivated to learn mathematics because they see the benefits of understanding mathematics for their future studies and careers (known as instrumental motivation for

learning mathematics). On average across OECD countries, $75 \%$ of students agree or strongly agree that making an effort in mathematics is worth it because it will help them in the work that they want to do later on; $78 \%$ agree or strongly agree that learning mathematics can improve their career prospects; $66 \%$ agree or strongly agree that they need mathematics for what they want to study later on; and $70 \%$ agree or strongly agree that learning many things in mathematics will help them get a job. Student responses to these questions were used to develop a composite index that captures students' motivation to learn mathematics because they perceive it as useful to them in the future. 
Percentage of students across OECD countries who reported "agree" or "strongly agree" with the following statements:

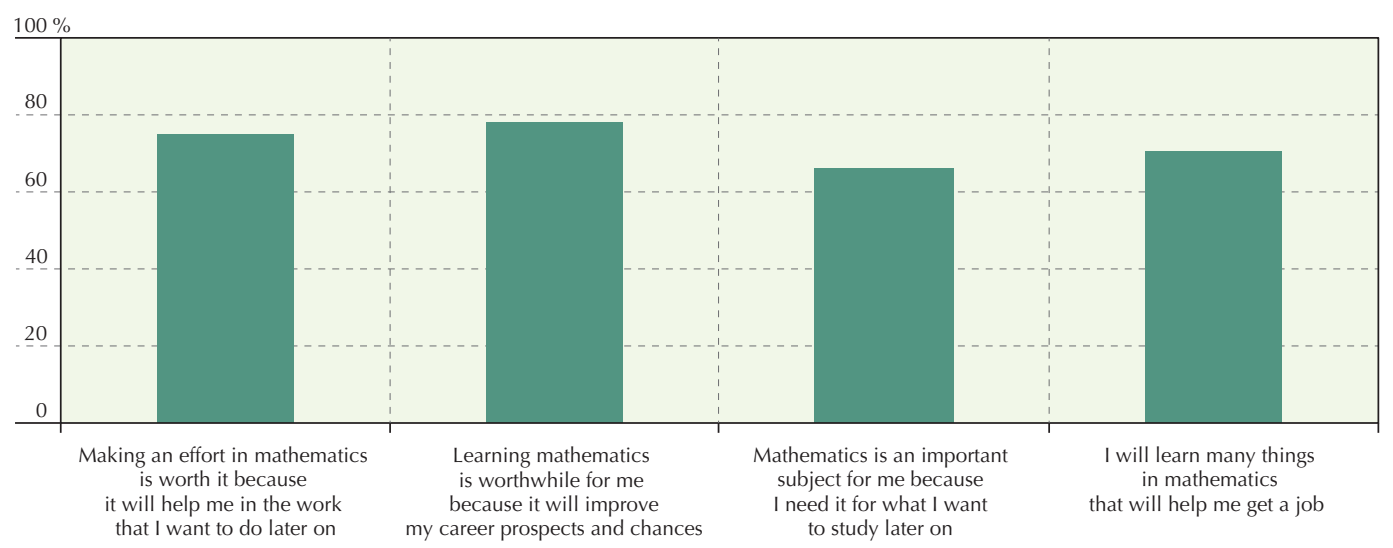

Source: OECD, PISA 2012 Database, Table III.3.5a

StatLink त्राज़ http://dx.doi.org/10.1787/888932963825

On average across OECD countries, the difference in mathematics performance between students who reported higher levels of motivation to learn mathematics and those with lower levels of motivation is 18 score points, or the equivalent of roughly half a year of schooling; in Korea, Norway and Chinese Taipei, the difference is greater than 30 score points. PISA also reveals that motivation is particularly strongly associated with performance among the highest-achieving students. On average across OECD countries, the difference in PISA scores associated with instrumental motivation is 21 points among top performers while it is only 11 points among low achievers. In Belgium, France, Hungary and the Slovak Republic, the score difference, related to motivation, between high and low performers is larger than 20 points.
The way students are assigned to programmes or schools is related to their motivation to learn...

But how is an individual student's motivation towards learning related to education policies that may be designed at the national level? PISA examined several policies that serve to group students between schools according to their interests and/or abilities. These policies include offering different programmes (such as vocational or academic programmes) to different students, defining the age at which students are admitted into these programmes, and determining the extent to which students' academic records are used to select students for admission into individual schools.

PISA results reveal that there is a strong negative association between the levels of students' motivation and the degree to which school systems sort and group students into different schools and/or programmes. In those systems that tend to separate students into different schools or programmes, students generally reported less instrumental motivation to learn mathematics than students in systems that tend not to separate students in that way. 


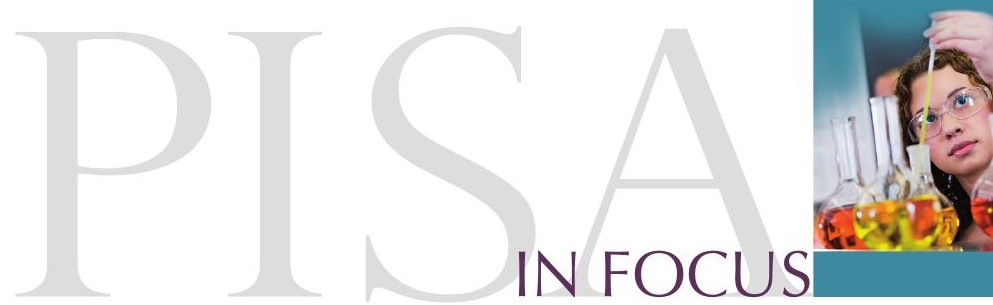

When different ways of grouping students between schools are examined, the findings suggest that students' motivation is lower in those school systems that offer a larger number of distinct education programmes; where larger proportions of students attend vocational or pre-vocational rather than academic programmes; where students are grouped or selected for these programmes at a younger age; where a large proportion of students attends academically selective schools; and where a large proportion of students attends schools that transfer students with low achievement, behavioural problems or special learning needs to another school.

For example, the Czech Republic and the Netherlands have 6 and 7 distinct education programmes, respectively, available to 15 -year-old students. Meanwhile, students in these countries have much lower levels of instrumental motivation to learn mathematics than students in Canada, the United Kingdom and the United States, where there is only one education programme available to 15 -year-old students. Similarly, in Austria, the Czech Republic and the Netherlands, students are first selected into different education programmes at the age of 10, 11 and 12, respectively. Students in these countries have much lower levels of instrumental motivation to learn mathematics than students in Iceland, New Zealand, the United Kingdom and the United States, where the age of selection is 16 .

\section{... and can have long-lasting consequences.}

While creating homogeneous student populations through grouping may allow teachers to direct classroom instruction to the specific needs of each group, selecting and sorting students generally acts as an indirect form of segregation that reinforces socio-economic disparities, results in differences in opportunities to learn, and consequently, de-motivates large numbers of students who do not feel they are being given equal opportunities to succeed. Indeed, selecting students in these ways implies that only some students can achieve at high levels, and thus runs the risk of de-motivating the very students who would benefit the most if their parents, their teachers and their schools held high expectations for them.
Relationship between instrumental motivation to learn mathematics and mathematics performance

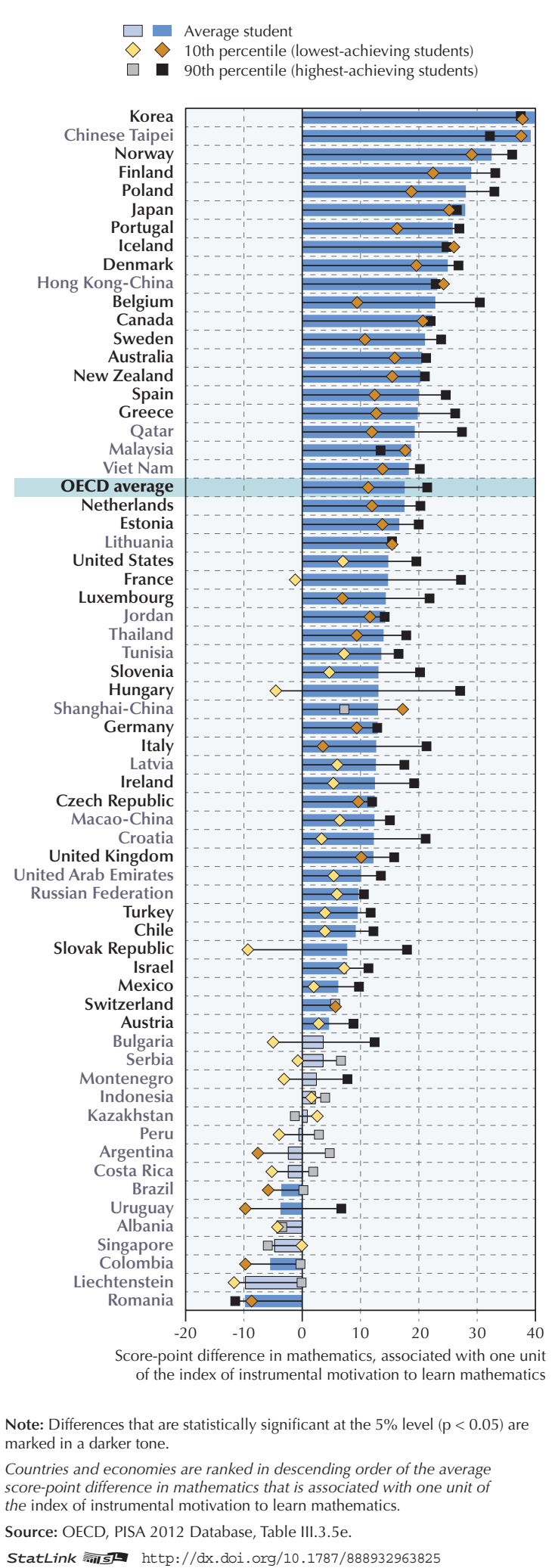

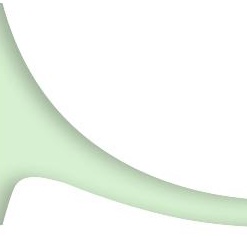


Students' motivation and grouping or selecting students for different schools

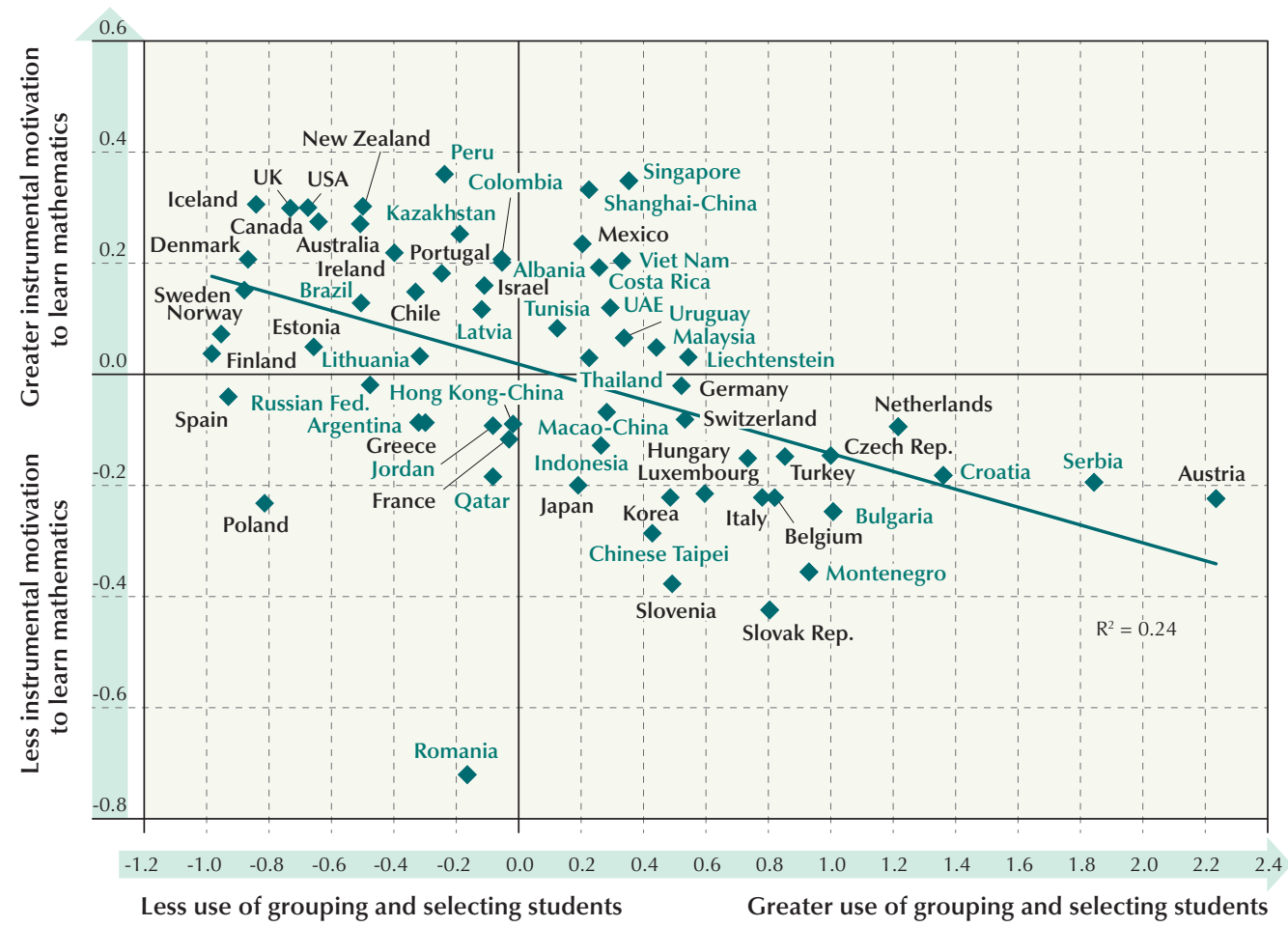

Source: OECD, PISA 2012 Database, Table IV.2.16.

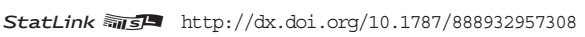

The bottom line: Student motivation is crucial for student both in and outside of school. School systems can promote student motivation by holding high expectations for all and by promoting policies and practices that are inclusive.

For more information

Contact Francesca Borgonovi (francesca.borgonovi@oecd.org)

See OECD (2013), PISA 2012 Results: What Makes Schools Successful? Resources, Policies and Practices (Volume IV), OECD Publishing, Paris;

OECD (2013), PISA 2012 Results, Ready to Learn: Students' Engagement, Drive and Self-Beliefs (Volume III), OECD Publishing, Paris.

\section{Visit}

www.pisa.oecd.org

www.oecd.org/pisa/infocus

Education Indicators in Focus

Teaching in Focus

Coming next month

Does pre-primary education reach

those who need it most?

Photo credit: @ khoa vu/Flickr/Getty Images @ Shutterstock/Kzenon @ Simon Jarratt/Corbis

This paper is published under the responsibility of the Secretary-General of the OECD. The opinions expressed and arguments employed herein do not necessarily reflect the official views of OECD member countries.

This document and any map included herein are without prejudice to the status of or sovereignty over any territory, to the delimitation of international frontiers and boundaries and to the name of any territory, city or area.

The statistical data for Israel are supplied by and under the responsibility of the relevant Israeli authorities. The use of such data by the OECD is without prejudice to the status of the Golan Heights, East Jerusalem and Israeli settlements in the West Bank under the terms of international law. 